\title{
studia
}

\section{Krzysztofa Celestyna Mrongowiusza przekład wykładów Kanta o religii i moralności (język i terminologia)}

W przedmowie do Krytyki praktycznego rozumu Kant dzieli się pewnymi obawami, co do zrozumienia swych pism przez szerszą publiczność. Obawy były uzasadnione, a podsycały je zapewne zarzuty, które wobec rzekomo niezrozumiałego języka i nowej terminologii rozpraw Kanta wysuwali tzw. filozofowie popularni ${ }^{1}$. Kant wyraźnie oświadcza, że z oskarżenia o rzekomo „nowy język” swych prac nic sobie nie robi, skoro zagadnienie, którego książka dotyczy, jest wystarczająco popularne. Nie uważa też, by sztucznie tworzył nieistniejące w języku terminy, tym bardziej, żeby głosił, iż nowe słowa są filozofii potrzebne. „Bardziej (niż owej niezrozumiałości) - czytamy w Krytyce praktycznego rozumu - boję się tu i ówdzie błędnego zrozumienia pewnych wyrażeń, które dobierałem $\mathrm{z}$ największą starannością, aby nie dopuścić do nieuchwycenia pojęcia, które one wskazują."

Wykłady Kanta dotyczące filozoficznej nauki o moralności są doskonałym przykładem deklarowanej ostrożności filozofa gdy idzie o dobieranie odpowiednich terminów oraz prób określenia znaczeń głównych pojęć. Wykłady o moralności, wygłaszane w formie komentarzy do łacińskiego kompendium, zostały spisane przez słuchaczy Kanta i przez wiele lat funkcjonowały jedy-

\footnotetext{
${ }^{1}$ I. Kant, Krytyka praktycznego rozumu, Kęty 2002, s. 25, przypis tłumacza.

2 Tamże.
} 
nie w postaci ręcznie sporządzonych odpisów. Pierwsze wydanie obszernych fragmentów wykładów o moralności nie zostało opublikowane w języku oryginału, ale w przekładzie na język polski. Autorem wydanego w 1854 roku w Gdańsku przekładu jest kaznodzieja luterański, Krzysztof Celestyn Mrongowiusz. By jednak uzasadnić kompetencje Mrongowiusza, gdy idzie o prawo do wprowadzania pewnych terminologicznych ustaleń w kształtującym się dopiero polskim języku filozoficznym, należy, tytułem wprowadzenia, pokrótce przypomnieć najważniejsze informacje dotyczące osoby tłumacza.

\section{\&}

Krzysztof Celestyn Mrongowiusz urodził się 19 lipca 1764 roku w Olsztynku. Ojciec, Bartłomiej Mrongowiusz, zajmujący wówczas urząd pastora i jednocześnie rektora szkoły parafialnej uznał, że właściwe wykształcenie Krzysztof Celestyn uzyska w Królewcu. Tam też w 1770 roku, po zakończeniu nauki w szkole elementarnej w Zalewie, wysyła swego syna, by rozpoczął edukację w szkole katedralnej na Knipawie. Po ukończeniu dwuletniej nauki w gimnazjalnych klasach szkoły katedralnej i pomyślnym zdaniu egzaminów, w wieku osiemnastu lat, 21 marca 1781 roku Krzysztof Celestyn Mrongowiusz został immatrykulowany na uniwersytecie Królewieckim jako „studiosus theologiae”, co potwierdza odpowiedni wpis na listę studentów Uniwersytetu Królewieckiego z $1781 \mathrm{roku}^{3}$. Na szczególną uwagę zasługuje data immatrykulacji, wynika z niej bowiem, że Mrongowiusz rozpoczął studia w Albertynie w okresie, na który przypada szczyt aktywności twórczej Immanuela Kanta. Studia, przerywane koniecznością udzielania korepetycji, Mrongowiusz kontynuował przez osiem lat. Kształcił się zwłaszcza w dziedzinie teologii oraz filologii, nie ulega wątpliwości, że uzyskał też wykształcenie filozoficzne, między innymi słuchając wykładów Kanta4

Dzięki studiom gruntownie przyswoił sobie polski język literacki; nauczył się rosyjskiego i czeskiego, a także opanował grekę, łacinę, hebrajski, francuski $\mathrm{i}$ angielski. Po ukończeniu nauki na uniwersytecie, w roku 1790 podjął pracę jako nauczyciel języka polskiego w Collegium Fridericianum. W 1797 roku Mrongowiusz opuścił Królewiec i osiedlił się w Gdańsku, gdzie objął posadę lektora języka polskiego w Gimnazjum Akademickim, a po spełnieniu prze-

\footnotetext{
3 „Mrongovius Christoph. Coelestin., Hohenst[ein]. Boruss.” (G. Euler, Die Matrikel der Universität Königsberg i. Pr., Bd. II, Leipzig 1911).

${ }^{4}$ Odnośnie do systemu kształcenia uniwersyteckiego w Królewcu za czasów Kanta por. M. Żelazny, Kantowska idea uniwersytetu, [w:] I. Kant, Spór fakultetów, Torun 2003.
} 
widzianych prawem formalności, rozpoczął pracę jako pastor w parafii ewangelickiej przy kościele św. Anny.

W Gdańsku Mrongowiusz kontynuował zapoczątkowane jeszcze w Królewcu badania nad gramatyką oraz nauczaniem języka polskiego. Rezultatem tych zainteresowań są publikacje podręczników oraz słowników. W późniejszym okresie życia Mrongowiusz powrócił do działalności translatorskiej. Wydał przekłady dzieł Ksenofonta, Teofrasta, Epikteta, Homera. Wiadomo, że pracował nad tłumaczeniem Platońskiego Fedona, które nie zachowało się. Wreszcie, rok przed śmiercią, opublikował będący przedmiotem naszego zainteresowania unikatowy przekład wykładów Immanuela Kanta o religii oraz moralności. Zmarł rok po publikacji Rozprawy filozoficznej..., 3 lipca 1855 roku w Gdańsku.

Interesujący nas przekład, który ukazał się pod tytułem Rozprawa filozoficzna o religii i moralności, stanowi kompilację dwóch niezależnych tekstów. Pierwsza, poświęcona religii część rozprawy została przełożona na podstawie istniejącego już wówczas drukowanego wydania wykładów Kanta o filozoficznej nauce religii (Immanuel Kant's Vorlesungen über philosophische Religionslehre), które w 1817 roku ukazało się w opracowaniu Karla Heinricha Ludwiga Pölitza. Znacznie bardziej obszerna druga część Rozprawy filozoficznej... została jednak przełożona bezpośrednio z rękopisu studenckich notatek (tzw. „Kolleghefte”) znajdujących się w posiadaniu Mrongowiusza. Tłumacz podkreśla to w przedmowie dołączonej do Rozprawy filozoficznej...:

Za czasów panowania Fryderyka Wielkiego, Króla Pruskiego żył w Królewcu szanowny Imanuel Kant, Profesor filozofii, który młodzieży akademickiej dawał lekcye, między innemi i w nauce o religii naturalnej i moralności. Jego ustne wykłady bywały przez niektórych słuchaczów z posłuchu spisywane. Z takich skoropisów utworzyło się niniejsze dziełko, które ja teraz spolszczone szanownej Publiczności jako drogi skarb ofiaruję.

Manuskrypt stanowiący podstawę części poświęconej nauce moralności, znany jako Moral Mrongovius, zachował się do naszych czasów i znajduje się w zbiorach Biblioteki PAN w Gdańsku (sygnatura: Ms. 2213)6.

\footnotetext{
${ }^{5}$ Rozprawa filozoficzna o religii i moralności miana przez Imanuela Kanta a na język polski przełożona przez Mrongowiusa, Kaznodzieje przy Kościele Św. Anny, i Kawalera Orderu Orła Czerwonego IV. Klassy, Gdańsk 1854, s. III.

${ }^{6}$ Dokładny opis widniejący na rękopisie Moral Mrongovius głosi: „Des beruhmten Professor [Immanuel] Kant zu Königsberg in Pr. philosophische Moral wie er się vorgelesen, eine treue
} 
Przekład Mrongowiusza jest szczególny z wielu powodów. Po pierwsze, stanowi pierwotne wydanie wykładów Kanta o moralności. Po drugie, publikacja ta ukazała się w języku polskim, a przekładu dokonał bezpośredni uczeń Kanta, słuchacz jego wykładów, a zatem osoba najbardziej uprawniona do wykonania tego zadania. Po trzecie, kompetencje translatorskie Mrongowiusza nie podlegają dyskusji również jako wieloletniego nauczyciela języków obcych oraz języka polskiego, autora podręczników oraz słownika polsko-niemieckiego oraz niemiecko-polskiego ${ }^{7}$.

Jakkolwiek przekład stanowi kompilację wybranych fragmentów wykładów o religii oraz notatek $\mathrm{z}$ wykładów o moralności, został jednak zredagowany w taki sposób, by w polskim wydaniu tworzył spójną całość. Język przekładu jest bardzo wierny, choć zawiera charakterystyczne neologizmy, zwykle będące kliszami terminów niemieckich. Neologizmy te na ogół nie przyjęły się w języku polskim. Można wymienić najbardziej charakterystyczne: „szkodoradość" (niem. Schadenfreude - złośliwe zadowolenie, złośliwa radość); świętoszenie, „człekolubość” (niem. Menschenliebe - miłość ludzka).

\section{Wykłady o moralności}

Zgodnie z obowiązującą w czasach Kanta praktyką, wykłady akademickie prowadzono, posługując się zalecanymi przez władze oświatowe podręcznikami. Wykłady z filozofii moralnej, które Kant prowadził w połowie lat siedemdziesiątych XVIII stulecia (przypuszczalnie w 1774/75), zachowały

Nachschrift von vielem Werth. [C. C.] Mrongovius”. Na końcu widnieje data: „1782 d. 11. Febr., zapewne data ukończenia manuskryptu. Krytyczne wydanie Moral Mrongovius ukazało się w 1979 roku w 27 tomie Kants gesammelte Schriften. W tej części opracowania podaję fakty ustalone przez prof. W. Starka i prof. M. Żelaznego i ogłoszone drukiem w: W. Stark, M. Żelazny, Zu Krzysztof Celestyn Mrongovius und seinen Kollegheften nach Kants Vorlesungen, [w:] Neue Autographen und dokumente zu Kants Leben, Schriften und Vorlesungen (Kant-Forschungen), hrsg. R. Brandt, W. Stark, Bd. 1, 1987 oraz M. Żelazny, Mrongowiusz jako wydawca wykładów Kanta, „Ruch Filozoficzny” 1987, nr 3-4. Krytyczne wydanie Rozprawy filozoficznej... wraz z odpowiadającym jej tekstem niemieckim ukazało się nakładem Wydawnictwa Naukowego UMK: I. Kant, Rozprawa filozoficzna o religii i moralności, przeł. K. C. Mrongowiusz, Toruń 2006.

${ }^{7}$ Kompetencje translatorskie Mrongowiusza podważano już w XIX wieku, przypisując mu nieznajomość języka polskiego, por. Powszechny Pamiętnik Nauk i Umiejętności, t. 2, Kraków 1835. Anonimowy recenzent stawia zarzuty wobec nadmiernego zamiłowania Mrongowiusza do kaszubszczyzny. Krytyce poddano także tendencję Mrongowiusza do tworzenia neologizmów oraz niewłaściwego stosowania nieodmiennych części mowy. 
się ogółem w trzynastu rękopisach. Kant wygłaszał je, korzystając z dwóch kompendiów Alexandra Gottlieba Baumgartena. Pierwsze z nich to Intitia philosophiae primae (Halae Magdeburgicae 1760), które służyło za podstawę wykładów z ogólnej filozofii praktycznej. Egzemplarz używany przez Kanta nie zachował się do naszych czasów. Drugie zaś to: Ethica philosophica (Halae Magdeburgicae, pierwsze wydanie 1740, drugie 1751 i trzecie 1763) podręcznik będący podstawą wykładów o etyce. Nie wiemy jednak, którego wydania używał Kant ${ }^{8}$. Podręczniki Baumgartena zostały zredagowane po łacinie, jedynie w trzecim wydaniu Ethica philosophica, opublikowanym po śmierci autora, uzupełniono tekst o niektóre niemieckie terminy. W notatkach z wykładów występuje sporo łacińskiej terminologii, również przekład Mrongowiusza zachowuje niektóre zwroty lacińskie (wszystkie jednak są oddane również po polsku).

Paul Menzer, redaktor pierwszego niemieckiego wydania wykładów Kanta o moralności, które zostało opublikowane w 1924 roku jako kompilacja trzech manuskryptów (w tym Moral Mrongovius), informuje w skrócie o stosunku Kanta do kompendiów Baumgartena'. Wiemy, że Kant odnosił się do tych podręczników z możliwie największą swobodą, często wyrażając swe niezadowolenie wobec zaproponowanej interpretacji. Interesujący - zdaniem Menzera - może być fakt, że Kant nie podejmuje w wykładach o moralności tematu inteligibilnej wolności (choć z pewnością został on już w tym czasie przez niego opracowany), brak tu zatem refleksji na temat podmiotu moralnego, który stanowiłby jedyny fakt świata ludzkiego niepodlegający determinacji świata przyrody. Menzer stawia tutaj pewną hipotezę i uznaje, że wykłady te są dowodem na to, że w okresie publikacji Krytyki czystego rozumu etyka Kantowska nie była jeszcze gotowa. Wydaje się, że Kant wprawdzie już dysponował odpowiednim budulcem, z którego mógłby powstać system etyki, jego finalizację powstrzymywał jednak brak przewodniej idei, stanowiącej spoiwo dla systematycznej całości. Dopiero wydane w 1785 roku Uzasadnienie metafizyki moralności dostarczyło brakującego ogniwa - imperatywu kategorycznego.

$\mathrm{Z}$ naszego punktu widzenia interesujące są dwie sprawy. Po pierwsze określenie znaczenia i zakresu podstawowych pojęć stosowanych przez Kanta

${ }^{8}$ Ethica philosophica $\mathrm{w}$ drugim i trzecim wydaniu została opublikowana w XXVII tomie Kant's gesammelte Schriften.

${ }_{9}^{9}$ P. Menzer, Einleitung (1924), [w:] I. Kant, Eine Vorlesung über Ethik, Frankfurt am Main 1990, s. $281 \mathrm{nn}$. 
(Ethik, Moral, Sittlichkeit). Po drugie, sposób, w jaki Mrongowiusz próbuje $\mathrm{w}$ języku polskim oddać sens niemieckich terminów.

\section{Określenie przedmiotu i zakresu etyki}

Każdy czyn („sprawa”) jest konieczny, jego wartość jednak zależy od motywu. W zależności od tego, czy motyw czynu zostaje powzięty na skutek przymusu czy z wewnętrznej dobroci, czyn jest, odpowiednio, jurydyczny bądź etyczny. $Z$ tego podziału wynika określenie etyki:

Etyka więc traktuje o wewnętrznej dobroci czynu; Jurisprudentia zaś o tym, co jest prawem. Ona się nie rozciąga do u m y s ł o w o ś c i c z y l i m y śl e n i a s p o s o b u, ale raczej do godziwości i przymusu; e t y c z n o ść z a ś z m i e r z a d o s a m ej u m y sło w o ś c i. Ona wprawdzie odnosi się i do jurydycznych ustaw, lecz ona wymaga, aby nawet takie sprawy, do których można być przymuszonym z powodu wewnętrznej d o b r o c i s e r c a, c z y l i u m y sło w o ś c i, a nie z samego tylko przymusu czyniono ${ }^{10}$.

Ten istotny cytat wymaga kilku wyjaśnień. Po pierwsze etyka (Ethik) zostaje oddzielona od jurysprudencji. Innymi słowy, oddzielona zostaje nauka o cnocie od nauki o prawie. Podział ten utrwali się w filozofii Kanta, pozostając w zgodzie z późniejszymi ustaleniami filozofii praktycznej (uzyskując pełną realizację w Metafizyce moralności). O ile nauka o cnocie dotyczy „wewnętrznej dobroci czynu” i „zmierza do samej umysłowości”, o tyle nauka o prawie odnosi się do ustaw określających wymagane bądź zabronione czyny. Nie jest jednak zamiarem Kanta przeciwstawienie etyki i prawa, dziedziny wolności zewnętrznej i królestwa wolności wewnętrznej (choć zostają one rozróżnione). Przeciwnie, postuluje on raczej, by nawet to, co wyznacza jurydyczna ustawa, było wykonywane zgodnie $\mathrm{z}$ wewnętrznym przekonaniem. Etyka rości pretensje do tego, aby każde postępowanie wypływało jedynie z wewnętrznej dobroci. Jej zakres ma więc się ustawicznie powiększać, także o te czyny, które jeszcze są wynikiem zewnętrznego przymusu.

Etyka nie jest więc taką nauką, która by żadnych przymusowych ustaw i czynów w sobie nie zawierała, lecz ona raczej rozciąga się na sprawy przymusowe, tylko że sama pobudka nie jest przymusem, ale raczej wewnętrzna jakość,

\footnotetext{
${ }^{10}$ Rozprawa filozoficzna, s. 39.
} 
wewnętrzny stan, wewnętrzna właściwość, czyli dobroć myśli. Etyka jest więc filozofią u m y s ł o w o ś c i, a za tym praktyczną filozofią, bo w ła s n o ś c i u m y s 1 u są zasadą naszych czynów i kojarznią czynów z pobudką ${ }^{11}$.

Etyka dotyczy tej wewnętrznej wartości czynu, „umysłowości” (Gesinnung), która bardzo często może pozostawać w sprzeczności z wypływającym z niego postępowaniem („sprawą”). „Nie trzeba więc z uczynków zewnętrznych acz mających wartość prawniczą zbyt skwapliwie dorozumiewać się owych s e n t y m e n t ó w (Gesinnung - T. K.)." ${ }^{12}$

Na podstawie powyższych fragmentów łatwo dostrzec, że miarą etyczności jest wyłącznie pobudka skłaniająca nas do działania albo, innymi słowy, jedynie te są etyczne, które wypływają z wewnętrznego przekonania, nie zaś z przymusu. Jakkolwiek te ostatnie mogą być również zgodne z prawem i dlatego należy im przyznać miano jurydycznych, to nie są wykonane w sposób, który pozwalałby je uznać za etyczne. „Kto ustawy z przymusu wykonywa, ten dla tego jeszcze nie będzie cnotliwym." ${ }^{13}$ Postępowanie takie może być legalne (tzn. zgodne z prawem), choć nie jest moralne (tzn. nie wypływa $\mathrm{z}$ obowiązku).

Używając terminologii wprowadzonej wyżej, można powiedzieć, że: „Etyka nazywa się też nauką cnoty; bo cnota zależy in rectitudine actionum ex principio interno t. i. prawości uczynków z zasady wewnętrznej”. Jej przedmiotem są „szczere chęci” (Gesinnung), z których wypływają czyny oceniane pod względem prawniczym.

Więc czyn, jaki może być wykonany w sposobie prawniczym albo etycznym. Dlatego mówią też, że ustawa prawnicza, czyli jurydyczna $\mathrm{n}$ i e $\mathrm{m}$ a $\mathrm{m}$ o $\mathrm{r}$ a ln o ści. W y r a z m o r a ln o ść stosuje się tylko do etycznych ustaw. Albowiem choć ustawy jurydyczne nie wyłączają moralnej konieczności lub wartości, wszelako ich pobudką jest przymus naglący, a nie dobrowolna chęć (Gesinnung - T. K.). Ponieważ nie mamy trafnego słowa na wyrażenie moralności, więc bierze się słowo obyczajność ${ }^{14}$.

Konkluzja: „Ponieważ nie mamy trafnego słowa na wyrażenie moralności, więc bierze się słowo obyczajność" (niem. Sittlichkeit) w oryginalnych zapi-

\footnotetext{
${ }^{11}$ Rozprawa filozoficzna, s. 39 (podaję numery stron pierwszego wydania; podkr. T. K.).

12 Tamże, s. 40.

13 Tamże.

14 Tamże, s. 40-41.
} 
skach z wykładów (Moral Mrongovius) została poprzedzona wyjaśnieniem, którego brakuje w polskim przekładzie. Przywoływane tutaj znaczenia terminów Ethik, Moral i Sittlichkeit wymagają dokładniejszego wyjaśnienia, którego niestety Mrongowiusz nie uwzględnia w polskim wydaniu, opuszczając fragmenty tekstu, mogące rzucić nieco światła, zwłaszcza na sens oraz powody zastosowania terminu Sittlichkeit. Spróbujmy przywołać nieuwzględnione Rozprawie filozoficznej... fragmenty Moral Mrongovius:

[Słowo] cnota nie wyraża dokładnie moralnej dobroci, oznacza ono raczej siłę samoopanowania i samokontroli ze względu na moralne usposobienie ( $\mathrm{Ge}$ sinnung). \{Rozważam tu jednak pierwotne źródło usposobienia (Gesinnung). $\}^{15}$ Jest to coś nieuchwytnego, co dopiero uświadamiamy sobie w następstwie, więc etyka ma jedynie usposobienie (Gesinnung) za swój przedmiot (Vorwurf). Słów \{obyczaj i\} obyczajowość (Sittlichkeit) używano na określenie moralności, jednakże obyczaj (Sitten) jest kwintesencją stosowności (Anständigkeit), natomiast do cnoty należy pewien stopień obyczajowej (sittlicher) dobroci, pewien przymus i samoopanowanie wywierane na samym sobie. [Pewne] ludy mogą posiadać obyczaje (Sitten), ale żadnej cnoty, \{np. Francuzi\}, inne [ludy] mogą posiadać cnotę, lecz żadnych obyczajów (Sitte). (Conduite jest wysubtelnionym obyczajem.) Nauka o obyczajach (Sitten) nie jest jeszcze nauką o cnocie, a cnota nie jest jeszcze żadną moralnością, ponieważ nie mamy innego słowa na wyrażenie moralności, więc bierzemy słowo obyczajność (Sittlichkeit) na oznaczenie moralności, bo nie moglibyśmy w odniesieniu do niej zastosować słowa cnota $^{16}$.

Wątpliwości może budzić trudność wyrażenia w języku znaczenia terminu „moralność. Należałoby jednak zwrócić uwagę na to, że z trzech wymienionych terminów (Ethik, Moral, Sittlichkeit) jedynie Sittlichkeit jest terminem niemieckim. Termin „etyka” (Ethik) jest kliszą słowa greckiego, „moralnośc” zaś (Moral) - łacińskiego. Można zatem uznać, że Kant, referując odpowiedni fragment łacińskiego kompendium, usiłuje wskazać odpowiednie niemieckie słowo, które mogłoby zastąpić obcą terminologię ${ }^{17}$. Pozostaje jednak pytanie,

${ }^{15}$ W klamrach podaję fragmenty tekstu znajdujące się w wydaniu Menzera, nieobecne w Moral Mrongovius.

${ }^{16}$ Kants gesammelte Schriften, Bd. XXVII, s. 1447.

${ }^{17}$ Jako uzupełnienie można by w tym miejscu przywołać obszerne hasło Sitte, zamieszczone w przez Mrongowiusza w słowniku niemiecko-polskim jego autorstwa:

„Sitte. f. (die) jede gleichformige Art des Verhaltens in Ansehung freier Handlungen, Gebrauch, Gewohnheit, Art und Weise, bes. die Fertigkeit außerer Handlungen in Ansehung des gesellscha- 
czy można precyzyjnie ustalić zakresy znaczeń podstawowych stosowanych w tekście terminów (i ich polskich odpowiedników). Kant z pewnością nie przeciwstawia sobie znaczenia terminów Moral i Sitte (Moralität i Sittlichkeit) $\mathrm{w}$ sensie, $\mathrm{w}$ jakim dokonuje tego na przykład Hegel ${ }^{18}$. Mrongowiusz utożsamia moralność i obyczajność nie tylko w swym przekładzie ${ }^{19}$, ale także w słownikach ${ }^{20}$. Nie oznacza to jednak, że dla własnych potrzeb nie dokonuje możliwie precyzyjnego określenia znaczeń słów, którymi się posługuje. Przyjrzyjmy się odpowiedniemu wyjaśnieniu, które zostało umieszczone w Metafizyce moralności:

W czasach starożytnych e t y k a oznaczała w ogóle $\mathrm{n}$ a u kę o moraln o ści i (philosophia moralis), którą nazywano także na u ką o ob o wi ą z $\mathrm{k}$ a ch. Potem uznano, że lepiej będzie stosować tę nazwę („etyka” - T. K.)

ftlichen Lebens nur im $\mathrm{Pl}$, vorzüglich zum rechtmaßigen außeren Verhalten; die guten Sitten, obyczaj, zwyczaj, g. aju; cf. obyczajność, eig. Sittlichkeit, uczciwość, przystojność, Anstandigkeit. Fr. obcych do nas przychodniów, było to zwyczajem, tuczyć się naszym chlebem, a pogardzać krajem. Es ist eine - des Landes taki jest zwyczaj tego kraju. Es ist der Welt - jest to zwyczaj świata. Gute Sitten dobre obyczaje. Bose Sitten złe obyczaje. Es ist nicht Sitte nie jest we zwyczaju. Bose Geschätze werden gute Sitten złe rozmowy psują dobre obyczaje; cf. z jakim przestajesz, takim się stajesz." C. C. Mrongovius, Dokładny Niemiecko-Polski Słownik. Ausfurliches Deutsch-Polnisches Wórterbuch, Dritte Auflage, Konigsberg 1854, s. 698.

18 „W niniejszej pracy Heglowski termin Sittlichkeit, przeciwstawiany Moralitat, tłumaczę zamiennie jako obyczajowość lub etyczność. Terminy te należy traktować jako synonimiczne i przeciwstawiać je pojęciu „moralność. Uważam, że polskie przeciwstawienie pojęć obyczajowość-moralność dość dobrze oddaje istotę zamiaru Hegla: obyczajowość dotyczy prawodawstwa rozumu praktycznego, które może być egzekwowane przez jakąś społeczność i którego należy przestrzegać bez względu na to, co się o jego konkretnych nakazach myśli (jak w obyczajowości rodzinnej), moralność zaś wiąże się z postulatem przezwyciężenia takiej dychotomii: prawa należy tu przestrzegać nie ze względu na egzekwującą je siłę, ale z wewnętrznego przekonania. Obyczajowość może się więc realizować drogą konfliktu jednostki z poczuciem własnej wolności, w przypadku moralności jest to wykluczone. Landmann oddaje z kolei Sittlichkeit jako etyczność, zaś sittlich jako etyczny, co w języku polskim nie akcentuje powyższego przeciwstawienia. Chcąc możliwie wiernie oddać sens myśli Hegla, nawiązując równocześnie do cytatów polskiego przekładu, w zależności od kontekstu używam więc pojęć obyczajowy i etyczny jako pary pojęć synonimicznych.” M. Żelazny, Heglowska filozofia ducha, Warszawa 2000, s. 131.

${ }^{19}$ Rozprawa filozoficzna, s. 43.

${ }^{20}$ Słowniki opracowane przez Mrongowiusza dostarczają interesujących obserwacji. Po pierwsze słownik niemiecko-polski odnotowuje identyczne znaczenia terminów Ethik oraz Moral: „etyka; nauka moralna, morały” (s. 283), „nauka moralna” (s. 526). Z kolei słownik polsko-niemiecki pomija słowo etyka, termin „moralność” definiuje zaś jako „Moralität, Sittlichkeit". 
wyłącznie do pewnego działu nauki o moralności, mianowicie do nauki o obowiązkach niepodlegających normom zewnętrznym, uznając, że właściwą nazwą dla tego jej działu w języku niemieckim będzie Tugendlehre („nauka cnoty”). $\mathrm{W}$ rezultacie obecnie system ogólnej nauki o obowiązkach dzieli się na n a u kę p r a w a (ius), która nadaje się do [ujęcia w postaci] norm zewnętrznych, i na n a u kę c noty (ethica), która się do tego nie nadaje, przy czym także my możemy pozostać ${ }^{21}$.

Termin „cnota” został przez Kanta już tutaj przedstawiony jako odpowiednik Gesinnung. W Uzasadnieniu metafizyki moralności Kant wyraźnie zastrzega, że używa terminu „cnota” na oznaczenie "moralnie dobrego usposobienia"22, maksym woli (ewentualnie ich źródła), które mogą, ale nie muszą ujawnić się w skutkach czynów. W omawianych wykładach, jak i w późniejszych pismach Kanta cnota jest rozumiana przede wszystkim (choć nie tylko) jako „siła samoopanowania i samokontroli”23 bądź jako „moralna siła woli człowieka w spełnianiu jego obowiązków” ${ }^{24}$, która w tym sensie pozwala wypełniać obowiązki, że umożliwia przeciwstawiać się skłonnościom zewnętrznie determinującym wolę. Jest zatem rozumiana jako pewien rodzaj męstwa (mores). Źródła tego oporu, moralnego męstwa, zdaniem Kanta, należy szukać w wewnętrznej dyspozycji człowieka - nazywanej mianem Gesinnung, charakterze, woli.

Etyka rozumiana jako nauka cnoty - używając terminologii zaproponowanej przez Mrongowiusza - dotyczy jedynie „umysłowości”, „myślenia sposobu” bądź „serca”. Terminy te odnoszą się do tego samego niemieckiego słowa Gesinnung, którego podobne bądź inne określenia znajdujemy na dalszych stronach przekładu: „właściwość umysłu” (s. 39), „dobrowolna chęć” (s. 40), „umysł” (s. 40, 48, 66, 68), „sentyment” (s. 40), „szczere chęci” (s. 40), „sposób myślenia” (s. 48, 78, 140, 171), „dobre serce” (s. 49), „myśli” (s. 62, 68, 73), „chęć” lub „wola” (s. 62, 73). Bardzo często, zważywszy wieloznaczność niemieckiego terminu, Mrongowiusz stosuje zbitkę dwóch - jego zdaniem odpowiadających sobie bądź uzupełniających się wzajemnie określeń, próbując w ten sposób dokładniej oddać znaczenie niemieckiego terminu: „umysł,

${ }^{21}$ I. Kant, Metafizyczne podstawy nauki o cnocie, Kęty 2005, s. 46. Metafizyka moralności zachowuje strukturę wykładów o moralności, zawarte w niej podziały w ogólnym zarysie odzwierciedlają porządek kompendium Baumgartena.

${ }^{22}$ I. Kant, Uzasadnienie metafizyki moralności, Warszawa 1953, s. 71.

${ }^{23}$ Kants gesammelte Schriften, Bd. XXVII, s. 1447.

${ }^{24}$ I. Kant, Metafizyczne podstawy nauki o cnocie, s. 74. 
czyli sposób myślenia”, „szczere chęci lub dobry umysł”, „sposób myślenia lub serce”, „chęci lub wola”.

Wprawdzie w wykładach czytamy, że „Trudno wyjaśnić, co się rozumie przez Gesinnung" 25 , jednak precyzyjne ustalenie znaczenia tego terminu jest tu kluczowe, zważywszy, że - jeśli można tak powiedzieć - oznacza ono właściwy zakres etyki: „Etyka jest więc filozofią umysłowości, a za tym praktyczną filozofią, bo własności umysłu są zasadą naszych czynów i kojarznią czynów z pobudką"26. Z braku definicji pozostaje jedynie uciec się do przykładów. O etycznej wartości czynu decyduje, zdaniem Kanta, jedynie Gesinnung. Etyczne będą tylko te czyny, które dokonywane są „ze szczerych chęci lub z dobrego serca” (aus guter Gesinnung), które są konsekwencją „sposobu myślenia” (Gesinnung), wreszcie - dokonywane są nie z przymusu, ale „dobrowolnie”, z własnej „chęci” (Gesinnung).

Obecnie termin Gesinnung na ogół oddaje się za pomocą rzeczownika „usposobienie” (sposób myślenia, przekonania), jednak znaczenie tego słowa znacznie wykracza poza moralny sens przypisywany tylko niektórym postawom i oznacza także dyspozycje czy charakter oraz wynikające z niego przekonania i zapatrywania. Słownik języka polskiego podaje następujące znaczenie słowa usposobienie: „zespół stałych cech charakteru, właściwy komuś sposób zachowania się; temperament, natura"27.

W przekładzie Krytyki praktycznego rozumu Benedykt Bornstein ${ }^{28}$ najczęściej stosuje wyraz „usposobienie” (s. 49, 85, 91, 92, 93, 96, 125, 129, 145, 149), zamiennie z terminem „intencja” (s. 83, 90, 156, 82, 120). Trudności związane z przekładem terminu Gesinnung były komunikowane przez tłumaczy. Roman Ingarden w jednym $\mathrm{z}$ komentarzy umieszczonym w Krytyce czystego rozumu zaznacza, że jest to: „słowo, które nie posiada odpowiednika w języku polskim; "usposobienie” tylko w przybliżeniu mu odpowiada. Kemp Smith oddaje je słowem „sentiments”, które posiada wiele różnych znaczeń. Tak samo tłumaczą Francuzi. Nie można go oddać słowem „uczucie” lub „uczucia”; w „Gesinnung” zawarte są bowiem z jednej strony trwałe

\footnotetext{
${ }^{25}$ Tekst opuszczony przez Mrongowiusza, por. Rozprawa filozoficzna, s. 39.

${ }^{26}$ Tamże.

${ }^{27}$ Słownik języka polskiego, red. M. Szymczak, Warszawa 1981.

${ }^{28}$ I. Kant, Krytyka praktycznego rozumu, Kęty 2002. Nie przywołuję tutaj przekładu Jerzego Gałeckiego, ponieważ w odpowiednich miejscach omawiany termin został przełożony dokładnie tak samo jak uczynił to Bornstein. Istotna jest jednak uwaga J. Gałeckiego, w której zawarte są pewne refleksje dotyczące możliwych sposobów tłumaczenia „Gesinnung” na język polski (I. Kant, Krytyka praktycznego rozumu, Warszawa 1972, s. 58).
} 
rysy charakteru etycznego człowieka, z drugiej żywione przez niego poglądy, a raczej jego sposób myślenia o różnych sprawach życiowych"29. Zwróćmy uwagę, że Mrongowiusz doskonale zdawał sobie sprawę z tej wieloznaczności, która z czasem uległa w przekładach sztampowemu ujednoliceniu. Odtąd Gesinnung niemal jednomyślnie, z niewielkimi wyjątkami, tłumaczono jako usposobienie, gdy tymczasem wszystkie wymienione przez Ingardena znaczenia („sentiments”, „uczucie”, „sposób myślenia”) stosowane są przez Mrongowiusza.

Tomasz Kupś

\begin{abstract}
The Translation of Kant's Lectures on Religion and Morals by Krzysztof Celestyn Mrongovius - its Language and Terminology.

The article consists of two complementary parts. The first one is a short presentation of the biography and scientific achievements of Krzysztof Celestyn Mrongovius (his studies in Königsberg, Kant's lectures, and publishing work). Mrongovius' manuscripts contain valuable collection of Kant's lectures, a part of which was published in Polish translation as early as in 1854. The other part of the paper deals with the chosen terminology of this unique translation with a special reference to the ambiguous term Geinnung.
\end{abstract}

${ }^{29}$ I. Kant, Krytyka czystego rozumu, Warszawa 1957, t. 2, s. 489. Po raz kolejny wątpliwości dotyczące sposobu tłumaczenia terminu Gesinnung zawarte zostały w rozdziale O ideale najwyższego dobra, gdzie tłumacz zaproponował, by zwrot „die moralische Gesinnung” przełożyć jako „charakter moralnie wartościowy”, opatrując swój przekład stosownym komentarzem (s. 556). 